\title{
The Issue of Disadvantaged Situation and Pandemic
}

\author{
Anna Perge \\ Faculty of Health, University of Miskolc, Assistant professor \\ Mariann Veresné Somosi \\ Faculty of Economics, University of Miskolc, Professor, Prof. Dr
}

\section{Abstract}

In the examination of the effects of the COVID-19 pandemic, special attention should be paid to the lagging areas. In the case of the settlements where we should reckon with social and economic backwardness and/or unemployment exceeding the national average, even the smallest change can move the life chances of people living there to a significantly negative direction. We would like to support the theory that the pandemic has resulted in further adverse consequences in disadvantaged settlements besides the existing economic and life quality disadvantages by research performed in Hungary. Besides the infrastructural deficiencies of the families' homes, it is also important to examine the infrastructural elements in terms of the settlements and health care, since health care, including human resources, is a cardinal issue in connection with the efforts to curb the pandemic. Besides these, we should reckon with the changes in the level of unemployment, the possible long-lasting incapacity for work. In the light of the research, it can be defined which professionals' presence and competencies are essential in disadvantaged settlements to prevent the further growth of disadvantages.

Keywords: pandemic, disadvantaged situation, multidisciplinary, infrastructure, competence

\section{Introduction}

Settlements which are beneficiary from a social, economic, or infrastructural aspect and/or suffer from significant unemployment ${ }^{1}$ demand special attention for both the workers of the economic, social or health sector and the legislators. Regarding the settlements where these characteristics exist, it should be taken into account that even the smallest change can move the life chances and future life prospects of the people living there to a significantly negative direction. During the examination of the

\footnotetext{
1 The Government Decree 105/2015. (IV. 23) is about the classification of the beneficiary settlements and the condition system of the classification.
} 
effects of the COVID-19 pandemic, great emphasis should be placed on the lagging areas, the areas where possible social and economic backlogs can be found, and unemployment often exceeding the national average, and unfavourable health prospects occur.

In terms of the distribution of the beneficiary settlements, one of the most affected regions of Hungary was the North-Hungarian region in $2020{ }^{1}$ which meant $25.69 \%$ of all the settlements with similar characteristics in the country, and $26.46 \%$ of the population of all the beneficiary settlements lived in this region. Significant differences can be detected even in this territorial unit: Borsod-Abaúj-Zemplén County shows exponentially higher numbers in terms of beneficiary settlements in comparison with the other counties. It should be mentioned that regarding all the counties in Hungary, most of these settlements can be found here $(17.97 \%$ of the national number, in terms of population it is the second with $18.94 \%$ of the national data). More initiations have been started to catch up this area (Rucska \& Kiss-Tóth, 2020, Kiss-Tóth \& Rucska, 2020, Felszeghi, 2015, Fritz \& Perge, 2020).

The study has searched the answer for the following questions: what further difficulties were caused or may be caused by the COVID-19 pandemic in this peripheral county, and what are the possibilities in decreasing further disadvantages?

\section{Literature Review}

Deprivation, the issue of disadvantaged situation has become a determining problem of these days. Not only as a negative social phenomenon we should deal with it, but it is the basis of difficulties occurring in several sectors, so its effects on the economic and health sectors are also determinative (Perge et al., 2020).

Disadvantaged situation means a life situation in which achieving a goal is so important for a certain person or group as for the other members of the society, but they are much more impeded in achieving these goals than the others. In the narrower interpretation of the international practice, those are in disadvantaged situation who can live only on a significantly lower level compared to the living standards and lifestyle of the average population of the certain region because of different causes. Furthermore, those are disadvantaged who may live in a different way than the average population or although their lifestyle is the same, but they can achieve this level only with significantly more efforts (Gidáné, 2006). So, with its complexity in mind, it can be told that it is independent from age and gender, and it can be the typical situation of both individuals and groups or communities.

That person, group, or community (a sub-population) is disadvantaged who/what differs from the average of the population in a biological, mental, somatic or social

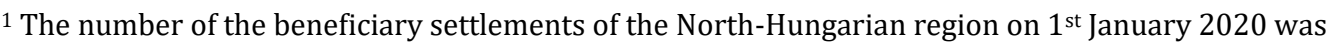
316 that meant 317778 persons in terms of the population.
} 
way. Disadvantaged situation is not just a private issue, it occurs in almost all forms of the communication with the society (Forrai et al., 2008).

\section{Methodology}

\subsection{Research goal}

The study uses the results of research performed in Hungary to support that what kind of further unfavourable consequences have been caused and may be caused by the pandemic besides the existing economic and life quality disadvantages in that disadvantaged region where the number of beneficiary settlements is especially high. In terms of the infrastructure, we examined both the infrastructural deficiencies of the families' houses and the infrastructural elements of the settlements, especially health care, since health care, and mainly the issue of human resources, is a cardinal issue in connection with the efforts to curb the pandemic. Besides these, we have to reckon with the changes in the level of unemployment, and the possible long-lasting incapacity for work.

The authors approach this much researched area of the disadvantaged situation from different aspects from the point of view of the real and possible effects of the pandemic - including but not limited to - with the aim of looking for innovative solutions. Relying on their research, they would like to point out to the areas which should be emphasized more, or which still should be given priority. In the light of the research, it can be defined which professionals' presence and competencies are essential in the disadvantaged settlements to prevent the further growth of disadvantages.

\subsection{Materials and methods}

Our data were collected from disadvantaged settlements in Hungary. The research in progress performed by the University of Miskolc Creative Region research group included in the Higher Education Institutional Excellence Program (in Hungarian: Felsőoktatási Intézményi Kiválósági Program, hereinafter: FIKP) started in 2018 in Borsod-Abaúj-Zemplén County means a determining part of the examined area. 25 disadvantaged settlements from one of the most backward areas of Hungary, the Abaúj region have been included in the research running for more than two years (Kiss-Tóth \& Rucska, 2020). The study also relies on one of the data collections performed by the Faculty of Health, University of Miskolc in connection with the pandemic started in 2019 which focused on the effects of the pandemic on the population. 


\section{Results}

\subsection{Housing conditions}

Data of 892 families $^{1}$ (from 23 settlements $^{2}$ ) in the Abaúj region were processed during the examination of the quality of the houses in the FIKP research program. The families' data were used in a summarized form and consequences were made broken down to settlements (Perge et al., 2020). In connection with a pandemic, the existence of infrastructural elements mapped by the FIKP research is especially important in families living in disadvantaged settlements. Working electricity could be found in almost $100 \%$ in all the settlements, so almost at all the 892 families. In contrary, tap drinking water (using water from a public well may also be included) showed a variable picture (Figure 1). Tap water supply around or less than $40 \%$ was typical in more than one third of the settlements, and there were settlements among them where it was a house quality characteristic determining health in only $20 \%$ of the families. Using gas is not widespread in this region: in one settlement, gas was introduced to the houses of about $80 \%$ of the people in care, in one settlement it was $60 \%$ and there was also one settlement where gas supply was around $50 \%$. On the other settlements the rate of using gas for heating was between 0 and $10 \%$ (Perge et al., 2020).

Figure 1: Infrastructure of the families' homes

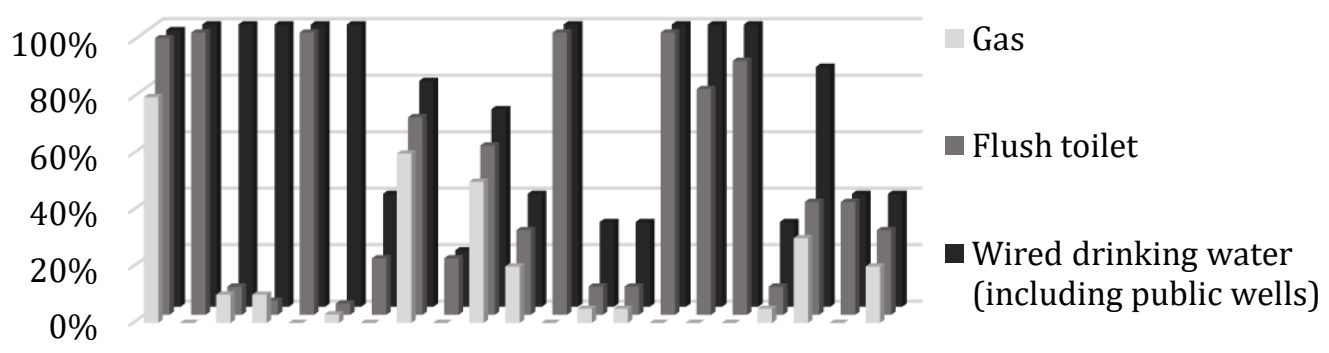

Source: edited by the author

\footnotetext{
1The common characteristics of the families: they raise children (there is at least one child between the age of 0 and 6 and/or a child between the age of 7 and 18 in mandatory school age but does not visit school) and/or there is a pregnant woman in the family.

In the cases of 2 settlements out of the 23 included in the research, there was not data recording in terms of the data published in this current paper, since they were ageing settlements.
} 
Heating system may determine the quality of the houses. In this region, the number of houses with a traditional heating system was significantly higher than houses heated by a centralized heating system. Housing poverty is also shown by the low number of bathrooms and, in a lot of cases, their total absence, and the rate of flush toilets. Based on the research, flush toilet could be found in those houses which also had a bathroom; according to the results, $100 \%$ of the families in care had a flush toilet on 4 settlements, and there were 3 settlements where half of the families in care had neither flush nor non-flushing toilets at all. Data processed in the research have highlighted that this serious house quality problem affects a great part of the region. The existence of a bathroom and a flush toilet showed an occurrence above $90 \%$ in 6 settlements in the houses of the families in care, but in 12 settlements the occurrence of them could not reach even 50\% (Perge et al., 2020).

Besides the detailed house quality problems and housing poverty, it is important to know the number of people living in the same household. In terms of families where there were any endangering causes (social, environmental and/or health), the number of people living in the same household was much higher than in families without endangering causes (Figure 2). In the non-vulnerable families, four people lived in a household on average, in the socially vulnerable families the number was six, it was 4.6 in families with endangered health, while 6.2 persons lived in the same household on average in families endangered both socially and in health (Perge et al., 2020).

Figure 2: The number of people living in the same household from the aspect of vulnerability

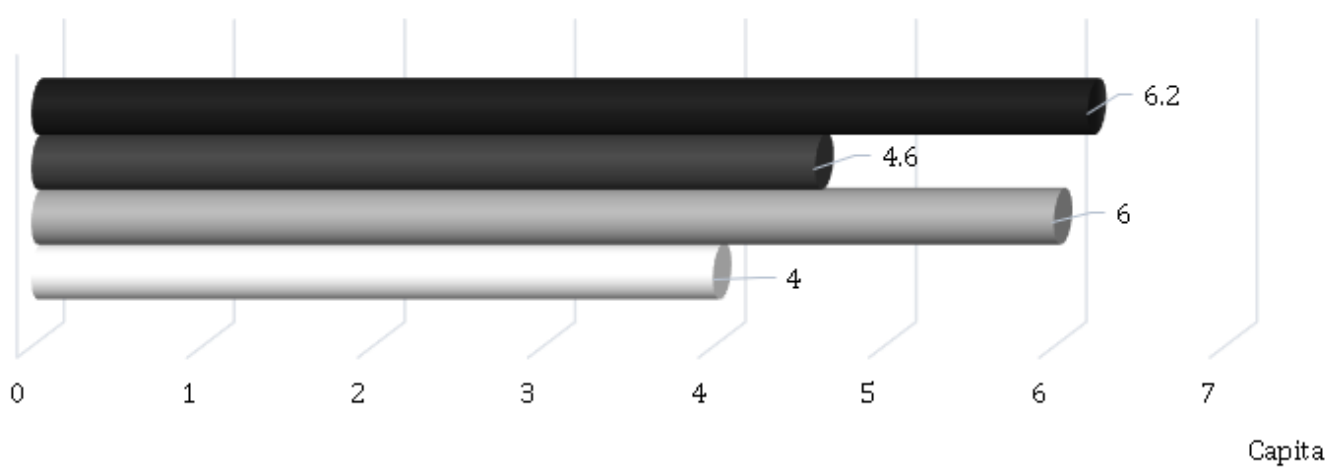

- Socially and medically vulnerable

Source: edited by the author 


\subsection{Provision of settlements in terms of health}

Those data are relevant in this current study which were collected based on an expert questionnaire and interviews (Perge et al., 2020) made with seven health visitors working in the primary care ${ }^{1}$.

It has been revealed in connection with the health care institutions that there are settlements where the working process tied to the health visitor's consulting room is usually performed in the physician's office. Modernizations can be found in the cases of some consultants that give the opportunity to use a health visitor's consulting room separately from the physician's office in different rooms. Additionally, in terms of the settlements' supply and infrastructure, the research also dealt with the existence of GP care and paediatric care. Data showed that there was a locally available paediatrician only in two settlements, there was a locally available GP supplying a mixed district (children and adults) in 8 settlements, however, people had to travel to another settlement for seeking medical care from 13 settlements. There were some villages in the sample from where people had to travel even 10 or 17 kilometres for this medical care. Regarding the office hours, people in care of 16 settlements could visit their doctor on every weekday, but the residents of 4 settlements could visit their nearest physician's office only on certain weekdays to have medical care. The answers show that medical care is performed by substitution on more settlements, the substitute doctor travels there once a week, and there are certain settlements which are very far from any kind of medical care. There were some settlements which had not had permanent GP care for decades, only a few families had a car, and bus transport was also rare; and all these circumstances influence the health status of people living there in a negative way. In case of 11 settlements, people had to travel to another place to have preventive health visitor's consultation that, based on the analyses of the health visitors' answers, was highly limited due to the public transport deficiencies in the region (Perge et al., 2020).

\subsection{The occurrence of unemployment}

528 people took part in the survey made on the Faculty of Health, University of Miskolc during the second Hungarian wave of the COVID-19 pandemic, 330 of them live in the North-Hungarian region. Based on all the answers, in connection with the labour market status, 13 of the fillers were unemployed, 9 of them lived in the NorthHungarian region. 3 from the 9 lost their jobs more than a year ago, 3 of them in 2020 and 3 of them lost their jobs during the 3 months preceding filling the questionnaire. It is important to mention that recording the questionnaire happened by "snowball" sampling during which those could fill it who had internet access.

In the frames of the FIKP research in Borsod-Abaúj-Zemplén County, the half-year interval of the public survey focusing on the adult population's health status and the factors determining it happened in the period of the pandemic. Data collection was

\footnotetext{
${ }^{1}$ Health visitors provide complex, preventive family protection service in Hungary.
} 
performed by the help of the colleagues of the Faculty of Health on the University of Miskolc by paper-based questionnaire method. Answers were filled by 227 adults living in beneficiary settlements. Data processing revealed that $29.07 \%$ of the respondents did not have a job at the time of answering and $19.38 \%$ did not have any kind of source of income. 8.81\% of the sample was pensioner, $14.1 \%$ was looking for a job and $7.9 \%$ did casual work. In terms of jobs, $13.22 \%$ of the respondents were public employees ${ }^{1}$. Based on the subjective judgement of their financial situation, $3.08 \%$ of the respondents thought that they were in a very good financial situation, $18.5 \%$ judged it as good, and $11.89 \%$ thought their financial situation to be bad or very bad, while a great proportion of the sample characterized it as adequate. Unemployed and working persons were in the same proportion among those who qualified their financial situation as bad or very bad, while people who judged their financial situation as very bad were mostly unemployed. The working people who thought their financial situation to be bad or very bad were mostly public workers, however, we could find seamstresses, unskilled workers, teachers or health workers among them as well. In terms of stress, livelihood problems meant the greatest stress factor for $27.75 \%$ of the respondents.

\section{Discussion}

From an epidemic point of view, regarding the secondary driving forces of the epidemic process, the most important ones are the changeable elements of the natural, artificial and social environment, such as water supply, sewerage, environmental pollution and livelihood conditions as well (Antmann, 2008). The analyses suggest that poverty and deprivation are typical for the living conditions of the families living in the Abaúj region. One of the areas most to be developed is the tapped water supply; among the examined settlements, we can find some where its existence can be estimated to $20 \%$. Overall, tap water supply is around or under $40 \%$ among the included families in 8 settlements out of 21 . It has turned out from the analyses that tap water supply in its own does not result in the same rate of the occurrence of flush toilets or bathrooms as water supply. However, in most cases, the existence of bathrooms and flush toilets was more common at the higher proportion of the occurrence, but in contrary, regarding their rate, it was significantly lower. Additionally, in the cases of 3 settlements, where all the families had wired tap water, the rate of bathrooms and flush toilets was 10, 5 and $4 \%$. The number of people living in the same household increases exponentially with vulnerability; in the mirror of these data, it can be concluded that quarantine or separation is not or hardly possible in their cases. Housing poverty can be interpreted as both a family and a social issue, the prevention of the development of further disadvantages originating from house quality problems means priority in a pandemic situation.

\footnotetext{
12011 CVI. law on public employment and amendments to laws related to public employment and other laws: get the working population to work, promote the employment of jobseekers
} 
Based on the especially high number of unfilled GP districts typical in the Abaúj region (the highest in Hungary) (Körösi \& Kiss-Tóth, 2020) and the background analyses, it can be stated that there is not any capacity for prevention and educational programs because of the low number of GP districts and the unfilled practices, and besides these, health visitors working in the primary care are overloaded, they deal with a high number of children (Takács, 2020).

According to the data of the research, a significant percent of the people living in the disadvantaged settlements did not have an employment relationship, they showed high unemployment typical for the settlements of the region.

In the questionnaire survey, unemployment was the most common among the respondents who could be reached personally by paper-based questionnaires, on-line answering was not an option in their cases. It can also be observed that there was not a significant difference between the number of unemployed and working people in the subjective judgement of the financial situation, but it showed a difference in its qualification: most of those who judged their financial situation as very bad did not have an employment relationship. Stress also occurs besides the issue of employment relationship and the judgement of the financial situation: more than $27 \%$ of the respondents in the disadvantaged settlements marked livelihood problems as the greatest stress factor.

\section{Conclusion}

One of the society's tasks is to help disadvantaged people institutionally on the field of prevention, and to contribute to prevent the development of disadvantaged situation (Forrai et al., 2008). People living in disadvantaged settlements - mainly regarding their health status - need appropriate health, educational and parenting services to break out from deep poverty and their deteriorating health status (Körösi \& Kiss-Tóth, 2020). A holistic point of view is needed to move the health of people living there to a positive direction, and to achieve that the effects of a possible epidemic influencing the quality of life could be decreased by developing well-being. These settlements require special attention, since besides the serious house quality problems, the existence of houses without comfort, emergency housing and the overload of the health care system, we have to reckon with the existing unemployment as well. Health care and the management of the competencies of people working in primary care are especially important in the case of an epidemic situation. The competency set of health visitors working in the Health Visitors' Service existing for more than a hundred years ago in Hungary has changed with the social demands since its existence, and it has always reflected for the certain public health problems, including the fight against TB (tuberculosis) (Kahlichné, 2015) and cervical cancer screening performed nowadays. Based on the Government Decree of the year of 2020 about the certain issues related to the health care and regular examinations suitable for detecting SARS-CoV-2 coronavirus, every student of the fields of medicine and health sciences can be assigned to perform the examination, without a license to 
pursue health activities (Government Decree No. 509/2020. (XI. 19)) which also supports the indispensability of human resources. One method to transfer knowledge and get possible extra competencies necessary for health workers to curb an epidemic is holding vocational trainings that can be performed on-line in our digitalized world.

\section{References}

[1] Decree No. 105/2015. (IV. 23) On the categorization of the beneficiary settlements and its condition system.

[2] Government Decree No. 509/2020. (XI. 19) on the regular testing of health and healthcare workers, workers in educational establishments, workers in social institutions and those working in crèches for the detection of SARS$\mathrm{CoV}-2$ coronavirus and certain health care issues

[3] 2011 CVI. law on public employment and amendments to laws related to public employment and other laws

[4] Antmann K. (2008): Általános járványtan. In: Tompa Anna (editor) Népegészségtani ismeretek, Budapest, Semmelweis Kiadó, pp.144-153.

[5] Felszeghi S. (2015): Egészségfejlesztési program Berente lakosainak a részére: készült Berente Háziorvosi rendelőjének morbiditási mutatói, környezeti monitorizálás, valamint a lakosság kérdőíves felméréseiből nyert adatok alapján. In: Kiss-Tóth, Emőke (editor) Lakossági egészségfelmérés és prevenciós egészségfejlesztő program Berentén, Miskolc, Magyarország: Miskolci Egyetem, pp. 107-130. Paper: 2. kiadás

[6] Forrai J., Bán D., Kaldau D.: A hátrányos helyzetűek közegészségtani vonatkozásai. In: Tompa Anna (editor) Népegészségtani ismeretek, Budapest, Semmelweis Kiadó, pp.310-315.

[7] Fritz P., Perge A, (2020): Egészségfejlesztő életmódprogram lehetséges elemei-intervenciós terv. In: Kiss-Tóth, Emőke (editor) Abaúj térség 14 év alatti gyermeklakosságának egészségmagatartása és fejlesztési lehetősége, Miskolc-Egyetemváros, Magyarország: Miskolci Egyetemi Kiadó, pp. 99-101.

[8] Gidáné Orsós E. (2006): A hátrányos helyzetről. Tudásmenedzsment 7.évf. 2. sz.

[9] Hungarikumok Gyűjteménye-Magyar Értéktár. Magyar Védőnői Szolgálat, mint nemzetközileg is egyedülálló, tradicionális ellátási rendszer

[10] Kahlichné Simon M. (2015): A védőnői hivatás története. Medicina Könyvkiadó Zrt.

[11] Kiss-Tóth E., Rucska A. (2020): Bevezetés. In: Kiss-Tóth, Emőke (editor) Abaúj térség 14 év alatti gyermeklakosságának egészségmagatartása és 
fejlesztési lehetősége, Miskolc-Egyetemváros, Magyarország: Miskolci Egyetemi Kiadó, pp. 9-10.

[12] Kőrösi A., Kiss-Tóth E. (2020): Az Abaúj térség 23 települése statisztikai adatainak vizsgálata az egészségi állapotot befolyásoló külső tényezők tükrében. In: Kiss-Tóth, Emőke (editor) Abaúj térség 14 év alatti gyermeklakosságának egészségmagatartása és fejlesztési lehetősége, Miskolc-Egyetemváros, Magyarország: Miskolci Egyetemi Kiadó, pp. 11-13.

[13] KSH (2020): On-line available: https://www.ksh.hu/docs/hun/xstadat/xstadat_eves/i_fol007.html

[14] Perge A., Rucska A., Kiss-Tóth E. (2020): A védőnői ellátottság jellemzői és az arra hatást gyakorló tényezők a vizsgált települések vonzásában. In: KissTóth, Emőke (editor) Abaúj térség 14 év alatti gyermeklakosságának egészségmagatartása és fejlesztési lehetősége, Miskolc-Egyetemváros, Magyarország: Miskolci Egyetemi Kiadó, pp. 19-35.

[15] Rucska A., Kiss-Tóth E. (2019): Halmozottan hátrányos helyzet, egészségkultúra: Általános iskolás fiatalok egészségmagatartása BorsodAbaúj-Zemplén megye halmozottan hátrányos településein. In: Karlovitz, János Tibor; Torgyik, Judit (editors) Szakmódszertani és más emberközpontú tanulmányok. Komárno, Szlovákia: International Research Institute, pp. 356-362.

[16] Takács I. (2020): Előszó. In: Kiss-Tóth, Emőke (editor) Abaúj térség 14 év alatti gyermeklakosságának egészségmagatartása és fejlesztési lehetősége, Miskolc-Egyetemváros, Magyarország: Miskolci Egyetemi Kiadó, p. 1. 